\title{
PENERAPAN STRATEGI MIND MAPPING DALAM MENGAJAR BAHASA INGGRIS PADA MATERI NEWS ITEM TEXT PADA SISWA KELAS XII- IPA SMAIT INSAN MANDIRI CIBUBUR
}

\author{
Iswadi \\ Guru Bahasa Inggris SMAIT Insan Mandiri Cibubur \\ Email : Iswasiidris30@gmail.com
}

\begin{abstract}
Abstrak
Mind mapping adalah strategi pembelajaran kreatif yang mengembangkan kemampuan siswa dalam membuat pemetaan konsep yang saling berhubungan sehingga membentuk sub-sub yang saling berhubungan. Pembelajaran bahasa Inggris pada Materi News Item Text pada siswa kelas XII-IPA SMAIT Insan Mandiri Cibubur dengan menggunakan Strategi Mind Mapping adalah sebagai berikut: 1. Guru memberikan memberikan salam dan memberikan alfazone yaitu dengan memberikan permainan membalik kata.2. Guru memberikan apersepsi yaitu guru menjelaskan tujuan pembelajaran dan manfaat materi bagi siswa serta memberitahukan kepada siswa karakter apa yang akan dikembangkan dalam pembelajaran.3. Guru menjelaskan materi news item text dan kemudian guru membagikan kertas warna-warni dan spidol untuk digunakan oleh siswa dalam membuat mind mapping.4. Siswa membuat mind mapping materi news item text dengan kertas dan spidol yang telah diterima.5. Guru membimbing siswa dalam membuat mind mapping materi news item text. 6. Guru memberikan konfirmasi yaitu guru memberikan pertanyaanpertanyaan kepada siswa tentang materi news item text. 7. Guru menyimpulkan materi news item text dan memberikan hikmah spiritual yang terkait dengan materi news item text.
\end{abstract}

Kata kunci: Strategi Mind Mapping, Materi News Item Text, Bahasa Inggris.

\section{PENDAHULUAN}

Kegiatan pembelajaran bahasa Inggris memerlukan pembelajaran yang kreatif dan inovatif sehingga siswa dapat belajar dengan semangat dan antusias. Siswa akan belajar dengan minat yang baik apabila guru mampu menyajikan pembelajaran yang dapat membuat siswa senang. Ketika siswa senang maka siswa akan mudah untuk menerima materi yang disampaikan oleh guru.

Pembelajaran yang bahasa Inggris di SMAIT Insan Mandiri Cibubur berusaha mengaitkan dengan kecerdasaan yang dimiliki oleh siswa dan gaya belajar siswa. Pengalaman penulis ketika mengajar dengan menggunakan metode pembelajaran ceramah ketika mengajar materi News Item Text, para siswa banyak yang tidak tertarik dan siswa banyak yang tidur sehingga proses pembelajaran yang penulis sajikan tidak berjalan dengan baik.

Berdasarkan masalah tersebut, penulis berusaha untuk memperbaiki proses belajar mengajar bahasa Inggris pada materi News Item Text dengan menyajikan strategi pembelajaran mind mapping. Harapannnya siswa akan belajar bahasa Inggris dengan 
mangaitkan kecerdasaan visual mereka dan siswa dapat belajar dengan kreatif dan inovatif.

Menurut Munjin (2009:110-111), Metode Mind Mapping (Peta Pikiran) adalah metode pembelajaran yang dikembangkan oleh Tony Buzana, kepala Brain Foundation. Peta pikiran adalah metode mencatat kreatif yang memudahkan kita mengingat banyak informasi. Setelah selesai, catatan yang dibuat membentuk sebuah pola gagasan yang saling berkaitan, dengan topik utama di tengah, sementara subtopik dan perincian menjadi cabang-cabangnya.

Penulis mengharapkan dengan metode pembelajaran mind mapping akan dapat melatih siswa untuk membuat konsep sebuah materi dan berlatih untuk mengembangkan kemampuan visual mereka.

Berdasarkan masalah tersebut, penulis tertarik untuk membuat karya ilmiah dengan judul," Penerapan Strategi Mind Mapping dalam mengajar bahasa Inggris pada Materi News Item Text pada siswa kelas XII-IPA SMAIT Insan Mandiri Cibubur". Berdasarkan latar belakang masalah di atas, masalah dibatasi pada: Penerapan Strategi Mind Mapping dalam mengajar bahasa Inggris pada Materi News Item Text pada siswa kelas XII-IPA SMAIT Insan Mandiri Cibubur. Berdasarkan pembatasan masalah di atas, rumusan masalah yang akan dijawab yaitu: Bagaimana Penerapan Strategi Mind Mapping dalam mengajar bahasa Inggris pada Materi News Item Text pada siswa kelas XII-IPA SMAIT Insan Mandiri Cibubur dan manfaatnya bagi siswa?

\section{TINJAUAN PUSTAKA}

\section{Pengertian Bahasa Inggris}

Bahasa Inggris adalah bahasa yang digunakan oleh berbagai macam Negara dengan tujuan untuk berbagai macam kepentingan untuk ilmu pengetahuan, politik, ekonomi, dan budaya. Blake (1996:2), menyatakan, bahwa, English is a branch of the West Germanic Family of languages which was brought to these islands from fifth century $A D$ on words by Germanic people known collectively as the Anglo-Saxons. Masih menurut, Blake (1996:1), menyatakan, English is used widely as a lingua Franca for purposes of commerce and science, because English has virtually achieved the status of a world language. For those who want to learn a second language, English is often their first choice. Berikutnya Benton (1971:1), menyatakan, bahwa : English has come to the 
first in the last Century, largery as a result of the increase in the population of the United States and of the British Common Wealth, but also stimulated by the role of English in commerce, communication, science, and technology. Crystal (2007:2), mengatakan, bahwa, English is a global language, they would say, you hear it on television spoken by politician from all over the world, wherever you travel you see English signs and advisement, wherever you enter the hotel or restaurant in a foreign city they will be understand English, and there will be an English men. Kemudian, Peters (2004:182), berpendapat,bahwa, English is the language of science and technology and the official medium communication for ships an aircraft. International organizations mostly use English, wheter associated with united nation or with sports management so do the major financial institutions, media networks, and travel organizations.

Berdasarkan kutipan di atas, peneliti menyimpulkan bahwa bahasa Inggris adalah bahasa global yang digunakan oleh masyarakat dunia untuk berbagai macam kepentingan seperti perdagangan, pendidikan, teknologi, ekonomi, politik, sosial, dan kebudayaan.

\section{Pengertian Hasil Belajar}

Belajar pastilah menghasilkan hasil belajar yang dapat bermanfaat bagi siswa baik itu yang berupa kemampuan, pengetahuan, ataupun sikap. Hidayat (2013:82), mengatakan, hasil belajar adalah kemampuan yang diperoleh anak setelah melalui kegiatan belajar. Dalam kegiatan belajar yang terprogram dan terkontrol yang disebut kegiatan pembelajaran atau kegiatan instruksional, tujuan belajar telah ditetapkan terlebih dahulu oleh guru, anak yang berhasil dalam belajar adalah anak yang berhasil mencapai tujuan-tujuan pembelajaran atau tujuan-tujuan instruksional.. Howard Kingsley (1957:45), membagi tiga macam hasil belajar yakni:a. Keterampilan dan kebiasaan; b. Pengetahuan dan pengertian; dan c. Sikap dan cita-cita. Gagne (1977:82), mengemukakan lima (5) kategori tipe hasil belajar yakni: a.Informasi verbal (verbal information); b. Keterampilan intelektual (intelektual skill); c. Strategi kognitif (Cognitive Strategy); d. Sikap (attitude); dan. e.Keterampilan motorik (motor skill). Bloom dalam Krathwol (1964:66), (menyatakan bahwa, awal mulanya ranah Kognitif (Cognitive Domain) terdiri dari jenjang kemampuan: (a) Pengetahuan (knowledge); (b) Pemahaman (Comprehension); (c) Penerapan (Application); (d) Analisa (Analysis);(e) Sintesa (synthesis); dan (f) Evaluasi (evaluation). Kemudian dengan adanya perkembangan ranah kognitif pendapat Bloom dikutip oleh Anderson dan Krathwohl, ranah kognitif terdiri 
atas jenjang kemampuan yaitu: (a) Remember (Mengingat); (b) Understand (Memahami); (c) Apply (Menerapkan); (d) Analyze (Menganalisis); (e) Evaluate (Menilai); dan (f) Create (Mencipta).

Berdasarkan teori-teori di atas, peneliti menyimpulkan bahwa hasil belajar bahasa Inggris adalah nilai bahasa Inggris siswa yang diperoleh siswa setelah menerima pembelajaran bahasa Inggris yang berupa kognitif, praktek, dan sikap.

\section{Pengertian News Items Text}

News Items Text adalah salah satu Jenis Teks Bahasa Inggris yang memberi informasi kepada pembaca mengenai kejadian-kejadian yang terjadi sehari-hari. Kejadian-kejadian tersebut yang disampaikan kepada pembaca adalah kejadian yang dianggap penting, hangat dan patut dijadikan berita.

Tujuan komunikatif dari News Items Text adalah memberitakan kepada pembaca, pendengar atau penonton tentang peristiwa-peristiwa atau kejadian-kejadian yang dipandang penting atau layak diberitakan.

Pada teks bahasa Inggris yang berjenis News Item Text, terdapat tiga bagian dalam setiap struktur kebahasaannya, yaitu: 1. Newsworthy Event Bagian pertama dari struktur kebahasaan News Item Text yang sering disebut Main Event adalah bagian yang menceritakan atau berisi berita tentang peristiwa atau kejadian inti yang biasanya dalam bentuk ringkasan atau summary. 2. Backgroud Event. Bagian kedua dari struktur kebahasaan News Item Text atau yang sering disebut juga dengan Elaboration adalah bagian yang menceritakan atau berisi tentang latar belakang peristiwa atau kejadian, siapa yang terlibat dan di mana tempat kejadiannya. 3. Source. Bagian terakhir dari struktur kebahasaan News Item Text adalah bagian yang menceritakan atau berisi tentang komentar, saksi kejadian, pendapat para ahli, dsb. mengenai peristiwa atau kejadian yang diberitakan. Di setiap teks bahasa Inggris yang berjenis News Item Text, terdapat ciri-ciri kebahasaan seperti berikut ini: Informasi singkat tertuang dalam headline, memfokuskan pada kejadian, menggunakan action verb, dan menggunakan material proses.

\section{Pengertian Mind Mapping}

Metode Mind Mapping (Peta Pikiran) adalah metode pembelajaran yang dikembangkan oleh Tony Buzana dalam Munjin dan Nur (209:110-111), Peta pikiran adalah metode mencatat kreatif yang memudahkan kita mengingat banyak informasi. 
Setelah selesai, catatan yang dibuat membentuk sebuah pola gagasan yang saling berkaitan, dengan topik utama di tengah, sementara subtopik dan perincian menjadi cabang-cabangnya.

Peneliti menyimpulkan bahwa mind mapping adalah strategi pembelajaran kreatif yang mengembangkan kemampuan siswa dalam membuat pemetaan konsep yang saling berhubungan sehingga membentuk sub-sub yang saling berhubungan.

Tony Buzana dalam Munjin dan Nur (209:112), Untuk membuat peta pikiran, guru hendaknya menggunakan bolpoint bewarna dan memulai dari bagian tengah kertas. Kalau bisa, guru menggunakan kertas secara melebar untuk mendapatkan lebih banyak tempat. Lalu ikuti langkah-langkah berikut; a. Tulis gagasan utamanya di tengah-tengah kertas dan lingkupilah dengan lingkaran, persegi, atau bentuk lain. b. Tambahkan sebuah cabang yang keluar dari pusatnya untuk setiap poin atau gagasan utama. Jumlah cabangcabangnya akan bervariasi, tergantung dari jumlah gagasan dan segmen. Gunakan warna yang berbeda untuk tiap-tiap cabang. c. Tuliskan kata kunci atau frase pada tiap-tiap cabang yang dikembangkannya untuk detail. Kata kunci adalah kata-kata yang menyampaikan inti sebuah gagasan dan memicu ingatan anda. Jika anda menggunakan singkatan tersebut sehingga anda dengan mudah segera mengingat artinya selama berminggu-minggu setelahnya. $\mathrm{d}$. Tambahkan simbol-simbol dan llustrasi-ilustrasi untuk mendapatkan ingatan yang lebih baik.

\section{METODE}

Metode yang digunakan adalah penelitian kualitatif dengan tujuan untuk mengembangkan penerapan strategi mind mapping dalam mengajar bahasa Inggris dengan materi News Item text.

Populasi dalam penelitian ini adalah siswa kelas XII-IPA SMAIT Insan Mandiri Cibubur yang berjumlah 14 siswa sehingga seluruh populasi dijadikan sebagai sampel penelitian.

Instrumen penelitian dengan menggunakan observasi dan teknik analisis data dengan menggunakan teknik analisis data yaitu teknik reduksi, penyajian data, dan verifikasi. 


\section{HASIL DAN PEMBAHASAN}

Penerapan Strategi Mind Mapping dalam mengajar bahasa Inggris pada Materi News Item Text pada siswa kelas XII-IPA SMAIT Insan Mandiri Cibubur. Pembelajaran bahasa Inggris pada Materi News Item Text pada siswa kelas XII-IPA SMAIT Insan Mandiri Cibubur dengan menggunakan Strategi Mind Mapping adalah sebagai berikut:

1. Guru memberikan memberikan salam dan memberikan alfazone yaitu dengan memberikan permainan membalik kata.

2. Guru memberikan apersepsi yaitu guru menjelaskan tujuan pembelajaran dan manfaat materi bagi siswa serta memberitahukan kepada siswa karakter apa yang akan dikembangkan dalam pembelajaran.

3. Guru menjelaskan materi news item text dan kemudian guru membagikan kertas warna-warni dan spidol untuk digunakan oleh siswa dalam membuat mind mapping.

4. Siswa membuat mind mapping materi news item text dengan kertas dan spidol yang telah diterima.

5. Guru membimbing siswa dalam membuat mind mapping materi news item text.

6. Guru memberikan konfirmasi yaitu guru memberikan pertanyaan-pertanyaan kepada siswa tentang materi news item text.

7. Guru menyimpulkan materi news item text dan memberikan hikmah spiritual yang terkait dengan materi news item text.

Siswa yang belajar dengan strategi pembelajaran Mind Mapping dapat meningkatkan kecerdasaan visual spasialnya karena siswa belajar untuk membuat gambar dan mewarnai dengan berbagai bentuk dan ragam hias. Siswa sangat antusias ketika mereka membuat mind mapping karena siswa diberikan kesempatan untuk mengembangkan kreativitasnya dalam belajar. Siswa yang belajar materi News Item Text dapat membuat mind mapping dengan memetakan tujuan penulis membuat teks news item text, generic structures, language features, dan contoh dari news item text, seperti contoh: 


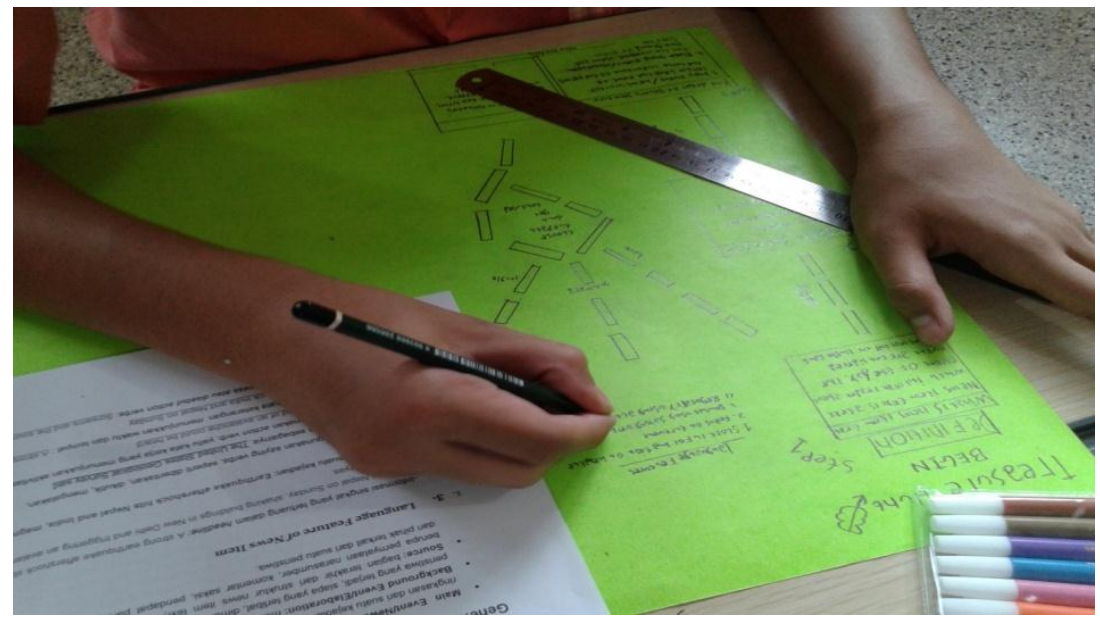

Gambar 1. Mind Mapping Materi News Item Text

Manfaat pembelajaran dengan strategi mind mapping pada materi news item text yaitu memberikan kesempatan kepada siswa untuk melibatkan kemampuan dalam berimajinasi membuat suatu konsep materi yang dapat mempermudah siswa dalam menguasai materi pembelajaran sehingga siswa mampu mendalami dan mengembangkan materi news item text dengan baik.

Oleh karena itu, strategi pembelajaraan mind mapping dapat bermanfaat bagi siswa kelas XII-IPA SMAIT Insan Mandiri Cibubur sebagai berikut: membantu mengembangkan kemampuan otak untuk berkonsentrasi dalam menguasai materi pembelajaran news item test, memungkinkan isi materi menjadi jelas dan mudah dipelajari dan dipahami, secara visual materi akan relatif lebih jelas urutan dan informasinya untuk dikuasai, membuat sambungan antara sub materi mudah untuk dilihat dan dipelajari, meningkatkan daya ingat menjadi Long term memory atau berjangka waktu panjang, meningkatkan keyakinan siswa dalam kemampuan untuk belajar.

Proses pembelajaran dengan strategi mind mapping melibatkan kombinasi unik yakni antara warna, dan pengaturan visual-spasial yang terbukti secara signifikan meningkatkan daya ingat siswa pada materi news item text. Seperti contoh pada gambar 2. 


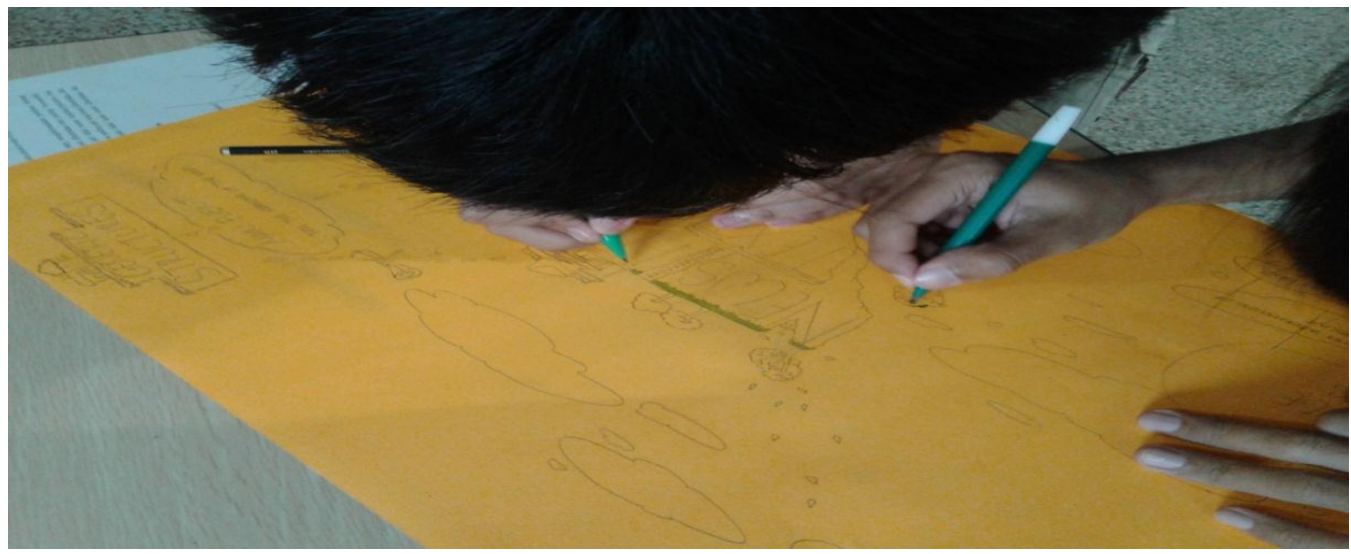

Gambar 2. Siswa sedang Manggambar dengan mewarnai Gambar Peta Konsep Pada Materi News Item Text

Kegiatan di atas telah membuat siswa untuk meningkatkan daya ingat siswa pada materi news item text karena siswa diberikan kesempatan untuk menggambar peta konsep dan mewarnai setiap hasil gambar yang dihasilkan sehingga proses pembelajaran menjadi kreatif dan inovatif.

Peran guru pada proses pembelajaran bahasa Inggris pada materi news item text dengan strategi mind mapping adalah sebagai motivator dan pemberi arah kepada siswa dalam membuat mind mapping. Guru bahasa Inggris harus dapat mengawasi dan memberikan cara bagaimana membuat mind mapping yang efektif dan sesuai dengan tujuan pembelajaran materi news item text. Guru harus dapat membuat siswa untuk belajar dengan serius dan senang sehingga siswa akan aktif dalam belajar, seperti gambar 3.

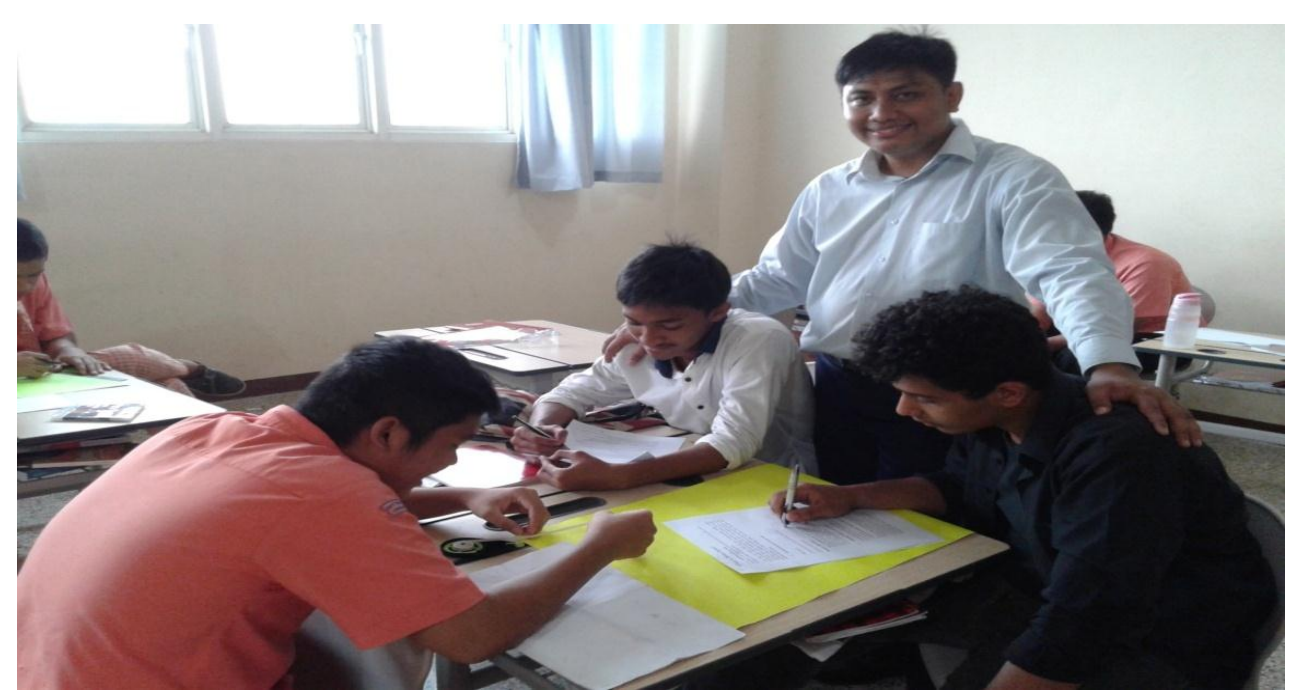

Gambar.3. Peran Guru Pada Proses Pembelajaran Bahasa Inggris Pada Materi News Item Text Dengan Strategi Mind Mapping 


\section{SIMPULAN DAN SARAN}

\section{Simpulan}

Berdasarkan pembahasan, penulis menyimpulkan hasil kajian sebagai berikut:

1. Mind mapping adalah strategi pembelajaran kreatif yang mengembangkan kemampuan siswa dalam membuat pemetaan konsep yang saling berhubungan sehingga membentuk sub-sub yang saling berhubungan.

2. Pembelajaran bahasa Inggris pada Materi News Item Text pada siswa kelas XIIIPA SMAIT Insan Mandiri Cibubur dengan menggunakan Strategi Mind Mapping adalah sebagai berikut: Guru memberikan memberikan salam dan memberikan alfazone yaitu dengan memberikan permainan membalik kata. Guru memberikan apersepsi yaitu guru menjelaskan tujuan pembelajaran dan manfaat materi bagi siswa serta memberitahukan kepada siswa karakter apa yang akan dikembangkan dalam pembelajaran. Guru menjelaskan materi news item text dan kemudian guru membagikan kertas warna-warni dan spidol untuk digunakan oleh siswa dalam membuat mind mapping. Siswa membuat mind mapping materi news item text dengan kertas dan spidol yang telah diterima. Guru membimbing siswa dalam membuat mind mapping materi news item text. Guru memberikan konfirmasi yaitu guru memberikan pertanyaan-pertanyaan kepada siswa tentang materi news item text. Guru menyimpulkan materi news item text dan memberikan hikmah spiritual yang terkait dengan materi news item text.

3. Pembelajaran bahasa Inggris pada Materi News Item Text pada siswa kelas XIIIPA SMAIT Insan Mandiri Cibubur dengan menggunakan Strategi Mind Mapping dapat meningkatkan kreativitas siswa dalam belajar bahasa Inggris dan meningkatkan kecerdasaan visual siswa.

\section{Saran}

Berdasarkan kesimpulan, saran yang diajukan penulis yaitu, guru bahasa Inggris harus menggunakan strategi pembelajaran mind mapping dalam mengajar bahasa Inggris siswa. 


\section{UCAPAN TERIMA KASIH}

Peneliti mengucapkan terimakasih kepada Direktur pendidikan YPSJ Bapak Munif Chatib yang telah memberikan ilmunya kepada semua guru di YPSJ dan Kepala Sekolah SMAIT Insan Mandiri Cibubur yang telah memberikan kesempatan kepada penulis untuk meneliti di kelas XII-IPA SMAIT Insan Mandiri Cibubur.

\section{DAFTAR PUSTAKA}

Ahamad Munjin Nasih dan Lilik Nur Kholidah 2009. Metode Dan Teknik Pembelajaran Pendidikan Agama Islam, (Bandung: PT Refika Aditama.

Benton, William. 1971. The English,Teaching Forum. London: Penerbit CUP

Blake,N.F. 1996. A History of the English Language.London: MACMILLAN PRESS LTD.

David Crystal. 2007. English As a Global Language.New York:Penerbit CUP

Howard Kingsley, 1957. The Nature and Conditions of Learning, NewJersey : Prentice Hall Ings Engliwood Clifts

Krathwohl, D. R. ed. et al. 1964, Taxonomy of Educational Objectives: Handbook II, Affective Domain. New York: David McKay

Peter,Pam. 2004. The Cambridge Guide to English Usage.Cambridge: Penerbit CUP

Robert M.Gagne, 1977. The Conditions of Learning. New York: Holt, Rinehart, and Winston

Syarif Hidayat, 2013. Teori dan Prinsip Pendidikan, (Tangerang: Pustaka Mandiri 